\title{
Governance and Financial Development: Evidence from the Middle East and North Africa Region
}

\author{
Badry Hechmy \\ *University of Tunis el Manar, Faculty of Economic Sciences and \\ Management of Tunis
}

Submitted: April 5, $2016 \bullet$ Accepted: September 27, 2016

\begin{abstract}
Since the 1990s, the promotion of good governance has been a priority for major international organizations such as the International Monetary Fund and the World Bank. This article aims to estimate the effect of institutional development on financial development in MENA countries during the period 1996 to 2013. Drawing on Demetriades and Luintel (1996) and Ito (2006), the econometric approach used is based on the GMM, the autocorrelation test for errors of Arellano and Bond (1991), and the over-identification test of Sargan for dynamic panel data. The results derived from this study show a considerable delay in financial development in MENA countries compared to several other emerging countries in Asia and Latin America. Furthermore, it shows a negative effect of institutional development on financial development. This unexpected relationship between these two variables has two explanations. First, the delusory level of institutional development of some countries in the region actually remains under the threshold beyond which it begins to positively affect the financial sector. Second, the political unrest experienced by the region during the study period has encouraged the informal financial sector to the detriment of the formal sector.
\end{abstract}

JEL classification: C23, O16, G28, G38

Keywords: financial deepening, governance, institutional development, MENA, GMM

${ }^{*}$ Corresponding Author. Email: Badrihechmi2013@gmail.com 


\section{Introduction}

There has been ongoing debate and extensive discussion about strategies to enable financial growth in developing countries. A few studies indicate that the quality and structure of financial institutions is based upon the important role of different political systems (La Porta et al., 1996), the institutional framework (Engerman and Sokoloff, 1994; Chinn and Ito, 2002), the development of telecommunications infrastructure, and computing and financial sector policies (Merton, 1992). Weak institutional development may explain the considerable delay in development of the financial sector in the Middle East and North Africa (MENA) countries compared to some emerging countries of South East Asia (such as Malaysia and South Korea) and Latin America.

In their financial and economic development and poverty reduction programs, major international organizations such as the International Monetary Fund and the World Bank provide guidelines to promote good governance. This paper reports on an analysis of the impacts of institutional and legal growth based on these guidelines, on the financial development of the MENA countries using a new econometric approach primarily based on the generalized method of moments (GMM) estimation approach for dynamic panel data models.

The remainder of this paper is divided into four sections. Section 1 summarizes the main theoretical and empirical results on the relationship between institutional development and financial deepening. Section 2 describes the empirical method used in this study. Section 3 reports and discusses the findings and Section 4 offers a conclusion.

\section{Review of the Theoretical and Empirical Literature}

The literature on the relationship between financial development and institutional development can be divided into three schools of thought to explain the level of financial development: the legal system, political factors, and social capital.

\subsection{Legal System and Financial System: The Theory of Law and Finance}

Legal and institutional frameworks can help explain the difference in the level of financial development observed between countries. In a country where the legal and judicial system strictly enforces the rights of private property, execution of contracts between economic agents, and the protection of legal rights of depositors, shareholders and investors, the financial markets will grow (La Porta et al., 1998; Beck and Levine, 2008). Indeed, such a system will restore confidence among the various economic agents (depositors, shareholders, 
and investors). Investors will increase their deposits with financial institutions, and this can lead to higher levels of investment. According to a study by Wurgler (2000), countries that respect the rights of creditors and shareholders benefit from an efficient allocation of credit against those countries where these rights are not respected. The less developed the judicial and legal system of a country is, causing investors and shareholders to be "afraid", the more are savings and investment levels lowered. This results in financial underdevelopment and reduces economic growth. By collecting data on firms in 20 countries, Love (2003) showed that financial constraints are more widespread in countries where the legal and judicial system is broken La Porta et al. (1998) showed that common law is more inclined to promote financial development, compared with other legal systems (French and Scandinavian).

\subsection{Importance of Political Factors}

Political factors can play a major role in determining the level of financial development in a country. When a group of people holds power, it creates an environment (political, institutional, and economic) that is profitable to them. The work of Rajan and Zingales (1998) showed that when the ruling class of a country is strongly constituted of landowning aristocrats, financial markets are poorly developed, but when power is largely held by businesspeople (traders, business leaders, industrialists, etc.), financial markets develop. Indeed, businesses need financial resources to boost their economic activities. They will, therefore, establish a climate or an environment conducive to attracting capital.

Based on the thesis of Myrdal (1963), Mama (2006) showed that it is necessary and desirable to establish a "strong state" and kill the "soft state" characterized by corruption, mismanagement, incompetence and inefficiency of public services, administrative delays, failure to respect laws, and misappropriation of public funds, that has prevented financial development in many African countries. ${ }^{1}$ In a soft state, the political powers may actually destabilize the functioning of financial markets because they borrow excessively from financial institutions without repaying the credit.

\subsection{The Role of Social Capital}

In the social science literature, the term social capital has several connotations. The terms usually used in the definition are: cooperative norms, confidence, and networks that enable people to act collectively (Putnam et al., 1994; Knack and Keefer, 1997). The efficiency of a market economy is based on perfect information. Financial markets are imperfect and characterized by information asymmetries between lenders and borrowers (Stiglitz and Weiss, 1981).

\footnotetext{
${ }^{1}$ Gunnar Myrdal received the Nobel Memorial Prize in Economic Sciences in 1974.
} 
In the presence of imperfect information situations in the financial markets, moral qualities (confidence, loyalty, etc.) can play an important role in financial development. Many exchanges between economic agents are made on the basis of confidence that enables a considerable reduction in transaction, monitoring, and information costs (Fukuyama, 1995). The loss of confidence of economic agents (depositors and lenders) resulting from the fear of nonrepayment of loaned capital and distrust of institutions and financial contracts, leads to a decrease in lending to the economy, thus narrowing financial markets.

It is clear that the confidence of economic agents in established financial contracts and the economic and institutional environment plays a major role in the development of financial markets, even in the case of noncompliance with laws (Galindo et al., 2001). By analyzing the effect of confidence on financial deepening in areas of northern and southern Italy, a study by Guiso et al. (2004) found that in areas where economic agents have greater confidence in one another, individuals have easy access to credit, investment rates are high, and the use of the informal financial market is weak.

\section{Empirical Method}

\subsection{Methodology}

The generalized method of moments ${ }^{2}$ (GMM) in dynamic panel data models, introduced by Holtz-Eakin et al. (1988) and Arellano and Bond (1991), solves the problems of simultaneity bias, reverse causality, and omitted variables. The GMM is better than the ordinary least squares estimator, because the latter is not consistent in the case of a dynamic model. ${ }^{3}$ There are two forms of GMM estimators in dynamic panels: the first difference GMM estimator and the GMM system estimator.

The method which Arellano and Bond (1991) proposed is a GMM first difference estimator. It involves taking, for each period, the first difference of the equation to be estimated to eliminate country specific effects, and instrumenting thereafter the explanatory variables of the first difference equation by their values lagged one period or more. The model of Blundell and Bond (1998) determined a GMM system estimator that combines the first difference equations with the level equations where the variables are instrumented by their first differences. The GMM system estimator seems better than the first difference GMM estimator as the latter estimator gives more biased results in the case of finite samples when instruments are weak.

\footnotetext{
${ }^{2}$ Levine et al. (2000) have provided detailed arguments justifying the use of GMM.

${ }^{3}$ In our case, a dynamic model is a model where one of its explanatory variables is a lagged dependent variable. This delayed explanatory variable will be correlated with the model error. Due to this correlation, the estimator of the ordinary least squares (and the generalized least squares) is not consistent.
} 
The study period ran from 1996 to 2013 and the sample was composed of 17 countries: Algeria, Bahrain, Egypt, Iran, Iraq, Jordan, Kuwait, Lebanon, Libya, Morocco, Oman, Qatar, Saudi Arabia, Syria, Tunisia, United Arab Emirates, and Yemen. The data used in this study came mainly from the World Bank database.

\subsection{The Model to Estimate}

The basic equation used for the econometric estimates is based on the work of Demetriades and Luintel (1996) and Ito (2006) on financial development. The dynamic equation is presented as follows:

$$
F D_{i, t}=\alpha \cdot F D_{i, t-1}+\beta \cdot I D_{i, t}+\gamma \cdot X_{i, t}+u_{i}+\varepsilon_{i, t}
$$

where:

- $F D_{i, t}$ : financial development in country i at time t;

- I $D_{i, t}$ : institutional development in country i at time t;

- $X_{i, t}$ : a vector of control variables such as GDP per capita $(P I B)$, inflation $(I N F)$, a composite index of financial liberalization $(F L)$;

- $u_{i}$ : the country-specific effect;

- $\varepsilon_{i, t}$ : the error term.

Definitions are provided in the following section for the composite variables in the dynamic equation as well as the macroeconomic variables considered in the context of this work, namely gross domestic product (GDP) per capita and inflation.

Composite index of financial development (FD). Several financial development indicators have been identified in the literature since the work of King and Levine (1993). Due to the availability of statistical data, this study makes use of only two of these financial development indicators: the money supply to GDP ratio $(M 2 / G D P)$, and private sector credit to GDP ratio $(P S C / G D P)$. Financial development refers to a strong mobilization of savings and the financing of the economy by financial institutions. $M 2 / G D P$ captures the mobilization of savings, whereas $P S C / G D P$ is used to measure the financing of the economy. These two indicators were built from World Bank statistical data. To capture overall financial development, it seemed appropriate to calculate the composite index; the latter is obtained in the following manner:

$$
F D_{t}=\frac{1}{2}\left(\frac{M 2_{t}}{P I B_{t}}+\frac{P S C_{t}}{P I B_{t}}\right)
$$


Index of financial liberalization (FL). We used the index of financial liberalization from the International Monetary Fund, which is calculated as the sum of the seven following indicators: credit control, interest rate controls, barriers to entry, banking supervision, privatizations, exchange control, and regulation of financial markets.

Index of institutional development (ID). Previously used by Kaufmann et al. (2006), the $I D$ is a composite index of five institutional development indicators: control of corruption $(C C)$, political stability $(P S)$, rule of law $(R L)$, regulatory quality $(R Q)$, and government effectiveness $(G E)$, and is obtained as follows:

$$
I D_{t}=\frac{1}{5}\left(C C_{t}+P S_{t}+R L_{t}+R Q_{t}+G E_{t}\right)
$$

GDP per capita. The variable GDP per head which captures economic growth can pose an endogeneity problem in equation (1). However, the use of GMM overcomes this difficulty. Some studies have shown that economic growth affects financial development (Schumpeter, 1934; King and Levine, 1995; Beck et al., 2000), whereas others revealed the opposite (Robinson, 1952).

Inflation (Inf). Inflation is likely to influence economic decisions, especially in terms of placement. A high inflation rate may discourage the use of financial intermediation and encourage investment in real assets (such as real estate, gold, oil, etc.). The level of inflation is often considered an indicator of financial repression, particularly because of seigniorage (McKinnon, 1973). These data come from World Development Indicators Database Archives.

\section{Results and Discussion}

We started with the residual autocorrelation test, the Sargan overidentification test, and stationarity test for panel data. In a second step, we conducted the estimation of results by the method of Arellano and Bond (1991). The Hansen test did not reject the hypothesis of validity of the lagged variables in levels and in differences as instruments. The residual autocorrelation test suggested that the hypothesis of no serial correlation of residuals could not be rejected.

\subsection{Stationarity Test for Panel Data}

We used the stationarity test of Im, Pesaran, and Shin (2003) (IPS) which is the most used due to certain relative advantages in comparison to other stationarity tests. For example, unlike the test by Levin and Lin (1993), the IPS test allows for heterogeneity of the autoregressive root and a heterogeneity regarding the presence of a unit root in the panel. 
Augmented Dickey-Fuller stationarity tests were applied separately for each country in the model, which can be written as follows:

- the model without trend:

$$
\Delta Y_{i, t}=\alpha_{i}+\rho_{i} Y_{i, t-1}+\sum_{j} \beta_{i, j} \Delta Y_{i, t-j}+\varepsilon_{i, t}
$$

- the model with trend:

$$
\Delta Y_{i, t}=\alpha_{i}+\rho_{i} Y_{i, t-1}+\delta_{i} t+\sum_{j} \beta_{i, j} \Delta Y_{i, t-j}+\varepsilon_{i, t},
$$

where $\alpha_{i}$ is the individual effect, $\varepsilon_{i, t} \sim N\left(0, \sigma_{\varepsilon}^{2}\right), i=1,2 \ldots N ; t=1,2 \ldots T$.

The IPS test consisted of testing the null hypothesis $\left(H_{0}\right)$ of nonstationarity for all countries against the alternative hypothesis $\left(H_{1}\right)$ of stationarity for at least one country.

$$
\begin{aligned}
& H_{0}: \quad \rho_{i}=1 \\
& H_{1}: \quad \rho_{i}<1
\end{aligned}
$$

The IPS-t statistic is the average of N-ADF individual statistics. The results of the IPS test (2002) stationary panel are shown in Table 1.

We note that all series were nonstationary when the trend was not taken into account, and they were stationary around a deterministic trend.

\subsection{Results of the Model by Arellano and Bond}

The lagged endogenous variable was statistically significant, assuming a positive sign, which indicated there was not a static relationship in the model, but a dynamic one. It also meant that countries that experienced an improvement in the ratio of financial development in a given year, also experienced an improvement in this ratio during the next year.

The financial liberalization coefficient was positive and significant; this result supports the thesis of McKinnon (1973) and Shaw (1973) that liberalization policy promotes financial deepening. Conscious that government intervention only allows the creation of several financial distortions, the majority of countries in the region started relative financial liberalization in the 1990s, with the help of international financial institutions. The restrictive policies adopted by MENA countries until that date, such as reserve requirements, the supervision of credit policy, and the preferred financing and administration of interest rates accompanied by high inflation rates have resulted in a reduction of loanable funds to businesses and a limit of bank competition. 
The low level of institutional development of the MENA countries affects negatively and significantly their level of financial development. This result is not surprising. In fact, there is a threshold at which institutional development begins to have a positive effect on the financial sector and this threshold has not been reached by some countries in the region. The improvement of the legal and institutional framework of those countries, in recent years, with the help of international institutions, has usually taken a long time to effect.

Afterward, even for countries with relatively developed institutional frameworks, the political unrest, Gulf War, Arab Spring, and terrorism that have been experienced by the region since the early 1990s have favored the informal financial sector to the detriment of the formal sector, which has reversed the relationship normally expected between institutional development and financial development.

According to the existing literature (La Porta et al., 1997, 1998; Levine, 1998; Wurgler, 2000; Barth et al., 2003; Edison, 2003; Acemoglu et al., 2008), the financial reforms that have been adopted by MENA countries can have adverse effects on the financial system (systemic crises) in countries with less developed institutional environments. Indeed, corruption, political instability, inefficient government actions, and the unreliability of the regulatory framework for financial activities that characterize these countries in the MENA region contribute to their financial underdevelopment.

An increase in the level of GDP per capita had a positive and significant effect on financial development. This result supports the "demand following" thesis of Patrick (1966) where financial development is a consequence of economic growth. A high inflation rate had a positive effect on financial development, but not a statistically significant one. The over identification Sargan test $(\mathrm{P}=0.1324)$ did not allow us to reject the hypothesis that the lagged variables were valid instruments in the model. Similarly, there is an absence of residual autocorrelation at order two $(\mathrm{P}=0.9287)$ but the residual autocorrelation is present at order one $(\mathrm{P}=0.0082)$, and the expected outcome for the GMM is better.

\section{Conclusion}

The results indicate that institutional development and financial development are negatively related. This can be explained, on the one hand, by the fact that the institutional reforms adopted by some countries in the region remain below the threshold at which the institutional development would start to have a positive effect on the financial sector, and, on the other hand, by the fact that the relationship between these two variables is perturbed by political turmoil experienced by the region during the studied period. If the level of institutional quality was high enough, most countries would have been able to improve their level of financial development. 
MENA countries have an interest in implementing strategies that support the fight against corruption and political instability, and improve the effectiveness of government actions and the quality of the regulatory framework. Control of corruption, respect for democratic principles, respect for laws and the legislature are important elements related to the success of any financial policy promoting sustainable economic growth.

Finally, a limitation of this study was the inability to examine the impact of another factor often underlined by the new literature as a natural complement to the institutional environment-social capital, which is measured by the level of confidence or cooperation between individuals. Norms that produce social capital must include substantial sincerity, loyalty, cooperation, and reciprocity. The relationship between social capital and financial development can be reduced to a financial contract between creditor and entrepreneur, which requires primarily a degree of trust between agents for the respect of contract terms. Future research could be directed at providing insight into the impact of social capital, and in particular, whether a high level of social capital is likely to develop financial contracts and, consequently, the financial markets.

\section{References}

Acemoglu, D., Johnson, S., Robinson, J. A., and Yared, P. (2008). Income and Democracy. American Economic Review, 98(3):808-42.

Arellano, M. and Bond, S. (1991). Some tests of specification for panel data: Monte Carlo evidence and an application to employment equations. The Review of Economic Studies, 58(2):277-297.

Barth, J. R., Nolle, D. E., Phumiwasana, T., and Yago, G. (2003). A Cross-Country Analysis of the Bank Supervisory Framework and Bank Performance. Financial Markets, Institutions $\mathcal{E}$ Instruments, 12(2):67-120.

Beck, T. and Levine, R. (2008). Legal Institutions and Financial Development, pages 251-278. Springer Berlin Heidelberg, Berlin, Heidelberg.

Beck, T., Levine, R., and Loayza, N. (2000). Finance and the sources of growth. Journal of Financial Economics, 58(1-2):261-300.

Blundell, R. and Bond, S. (1998). Initial conditions and moment restrictions in dynamic panel data models. Journal of Econometrics, 87(1):115-143. 
Chinn, M. D. and Ito, H. (2002). Capital Account Liberalization, Institutions and Financial Development: Cross Country Evidence. Working Paper 8967, National Bureau of Economic Research.

Demetriades, P. O. and Luintel, K. B. (1996). Financial Development, Economic Growth and Banking Sector Controls: Evidence from India. The Economic Journal, 106(435):359-374.

Edison, H. (2003). Testing the Links. How Strong Are the Links Between Institutional Quality and Economic Performance? Finance and Development, 40(2):35-37.

Engerman, S. L. and Sokoloff, K. L. (1994). Factor Endowments: Institutions, and Differential Paths of Growth Among New World Economies: A View from Economic Historians of the United States. Working Paper 66, National Bureau of Economic Research.

Fukuyama, F. (1995). Trust: The Social Virtues and the Creation of Prosperity. New York: Free Press.

Galindo, A. J., Chong, A., and Calderón, C. A. (2001). Structure and Development of Financial Institutions and Links with Trust: Cross-Country Evidence. IDB Publications (Working Papers) 6482, Inter-American Development Bank.

Guiso, L., Sapienza, P., and Zingales, L. (2004). The Role of Social Capital in Financial Development. American Economic Review, 94(3):526-556.

Holtz-Eakin, D., Newey, W., and Rosen, H. S. (1988). Estimating Vector Autoregressions with Panel Data. Econometrica, 56(6):1371-1395.

Im, K. S., Pesaran, M., and Shin, Y. (2003). Testing for unit roots in heterogeneous panels. Journal of Econometrics, 115(1):53-74.

Ito, H. (2006). Financial development and financial liberalization in Asia: Thresholds, institutions and the sequence of liberalization. The North American Journal of Economics and Finance, 17(3):303-327.

Kaufmann, D., Kraay, A., and Mastruzzi, M. (2006). Governance matters V: aggregate and individual governance indicators for 1996 - 2005. Policy Research Working Paper Series 4012, The World Bank.

King, R. G. and Levine, R. (1995). Financial Intermediation and Economic Development. In Mayer, C. and Vives, X., editors, Capital Markets and Financial Intermediation, pages 156-189. Cambridge University Press, Cambridge/New York/Melbourne. 
Knack, S. and Keefer, P. (1997). Does Social Capital Have an Economic Payoff? A CrossCountry Investigation. The Quarterly Journal of Economics, 112(4):1251-1288.

La Porta, R., de Silanes, F. L., Shleifer, A., and Vishny, R. W. (1997). Trust in Large Organizations. The American Economic Review, 87(2):333-338.

La Porta, R., de Silanes, F. L., Shleifer, A., and Vishny, R. W. (1998). Law and Finance. Journal of Political Economy, 106(6):1113-1155.

La Porta, R., Lopez-de Silane, F., Shleifer, A., and Vishny, R. W. (1996). Trust in Large Organizations. Working Paper 5864, National Bureau of Economic Research.

Levin, A. and Lin, C.-F. (1993). Unit Root Tests in Panel Data: New Results. University of California at San Diego, Economics Working Paper Series.

Levine, R. (1998). The Legal Environment, Banks, and Long-Run Economic Growth. Journal of Money, Credit and Banking, 30(3):596-613.

Levine, R., Loayza, N., and Beck, T. (2000). Financial intermediation and growth: Causality and causes. Journal of Monetary Economics, 46(1):31-77.

Love, I. (2003). Financial Development and Financing Constraints: International Evidence from the Structural Investment Model. Review of Financial Studies, 16(3):765-791.

Mama, T. (2006). Pour la mort de l'État en Afrique: de quel État faut-il souhaiter la mort? In Bekolo-Ebe, B., Mama, T., and Fouda, S. M., editors, Mondialisation, Exclusion et Dveloppement Africain: Stratgies Des Acteurs Publics et Privs, volume 2, pages 453-463. Maisonneuve \& Larose.

McKinnon, R. I. (1973). Money and Capital in Economic Development, 1973. Washington, DC: The Brookings Institution.

Merton, R. C. (1992). Financial Innovation and Economic Performance. Journal of Applied Corporate Finance, 4(4):12-22.

Myrdal, G. (1963). Challenge to Affluence: The Emergence of an Under-Class. New York: Pantheon Books.

Putnam, R., Leonardi, R., and Nanetti, R. (1994). Making Democracy Work: Civic Traditions in Modern Italy. Princeton paperbacks. Princeton University Press.

Rajan, R. G. and Zingales, L. (1998). Financial Dependence and Growth. American Economic Review, 88(3):559-86. 
Robinson, J. (1952). The Model of an Expanding Economy. The Economic Journal, $62(245): 42-53$.

Schumpeter, J. A. (1934). The Theory of Economic Development: An Inquiry into Profits, Capital, Credit, Interest and the Business Cycle. Cambridge, MA: Harvard University Press.

Shaw, E. (1973). Financial Deepening in Economic Development. Economic Development Report. Oxford University Press.

Stiglitz, J. E. and Weiss, A. (1981). Credit Rationing in Markets with Imperfect Information. American Economic Review, 71(3):393-410.

Wurgler, J. (2000). Financial markets and the allocation of capital. Journal of Financial Economics, 58(1-2):187-214. 
Table 1: IPS Test

\begin{tabular}{lccccc}
\hline Variable & FD & FL & ID & GDP & INF \\
\hline Model Without Trend & $\mathrm{I}(1)$ & $\mathrm{I}(1)$ & $\mathrm{I}(1)$ & $\mathrm{I}(1)$ & $\mathrm{I}(1)$ \\
Model With Trend & $\mathrm{I}(0)$ & $\mathrm{I}(0)$ & $\mathrm{I}(0)$ & $\mathrm{I}(0)$ & $\mathrm{I}(0)$ \\
\hline
\end{tabular}

Note: I(0) means that the series are stationary in a panel at the $5 \%$ significance level. I(1) means that series are not stationary in a panel.

Table 2: GMM Estimation

\begin{tabular}{lccc}
\hline Variable & Coefficient & Standard Error & $\mathbf{t}_{c a l}$ \\
\hline FD $_{\text {lagged }}$ & $0.431^{*}$ & 0.08211 & 5.24 \\
FL & $0.00062^{*}$ & 0.00021 & 2.88 \\
ID & $-0.00311^{*}$ & 0.0002 & -15.55 \\
GDP & $0.00061^{*}$ & 0.00021 & 3.11 \\
INF & 0.000001 & 0.000023 & 0.045 \\
Constant & $0.03251^{*}$ & 0.0053 & 6.2 \\
\hline Sargan test: & 0.1324 & & \\
Arellano-Bond test for $\mathbf{A R}(\mathbf{2})$ in first differences: $\mathrm{z}=-3.4$ \\
Arellano-Bond test for $\mathbf{A R}(\mathbf{1})$ in first differences: $\mathrm{z}=-2.72^{*}$ \\
\hline
\end{tabular}

Note: ${ }^{*}$ coefficient significant at the $5 \%$ level, ${ }^{* *}$ coefficient significant at the $10 \%$ level. 